\title{
Effect of bacterial ice nuclei on the frequency and intensity of lightning activity inferred by the BRAMS model
}

\author{
F. L. T. Gonçalves ${ }^{1}$, J. A. Martins ${ }^{2}$, R. I. Albrecht ${ }^{3}$, C. A. Morales ${ }^{1}$, M. A. Silva Dias ${ }^{1}$, and C. E. Morris ${ }^{4}$ \\ ${ }^{1}$ Dept. of Atmospheric Sciences, IAG/USP/Brazil, Rua do Matão 1226, 05508090, São Paulo, SP, Brazil \\ ${ }^{2}$ Universidade Tecnológica Federal do Paraná, 86036-370, Londrina, PR, Brazil \\ ${ }^{3}$ DSA/CPTEC, Instituto Nacional de Pesquisas Espaciais, Cachoeira Paulista, SP, Brazil \\ ${ }^{4}$ INRA, UR407 Pathologie Végétale, 84140 Montfavet, France
}

Correspondence to: F. L. T. Gonçalves (fgoncalv@model.iag.usp.br)

Received: 20 April 2011 - Published in Atmos. Chem. Phys. Discuss.: 21 September 2011

Revised: 1 June 2012 - Accepted: 4 June 2012 - Published: 2 July 2012

\begin{abstract}
Many studies from the last decades have shown that airborne microorganisms can be intrinsically linked to atmospheric processes. Certain bacteria may constitute the most active ice nuclei found in the atmosphere and might have some influence on the formation of ice crystals in clouds. This study deals with the ice nucleation activity of Pseudomonas syringae inside of thunderstorms through numerical simulations using BRAMS (Brazilian Regional Atmospheric Model System). The numerical simulations were developed in order to investigate the effect on the total amount of rainwater as a function of ice nuclei (IN) $P$. syringae concentrations with different scenarios (classified as $\mathrm{S} 2$ to $\mathrm{S} 4$ scenarios) corresponding to a maximum of $10^{2}$ to $10^{4} \mathrm{IN}$ bacteria per liter of cloud water plus the BRAMS default (classified as S5 scenario). Additionally, two other scenarios were included without any IN (S1) and the sum of RAMS default and S4 scenario (classified as S6). The chosen radiosonde data is for 3 March 2003, typical summertime in São Paulo City which presents a strong convective cell. The objective of the simulations was to analyze the effect of the IN concentrations on the BRAMS modeled cloud properties and precipitation. The simulated electrification of the cloud permitted analysis of the total flashes estimated from precipitable and non-precipitable ice mass fluxes in two different lightning frequencies. Among all scenarios, only S4 and S6 presented a tendency to decrease the total cloud water, and all bacteria scenarios presented a tendency to decrease the total amount of rain $(-8 \%)$, corroborating other reports in the literature. All bacteria scenarios also present higher precipitable ice concentrations compared to S5 sce-
\end{abstract}

nario, the RAMS default. The main results present the total flash number per simulation as well. From the results, the total flash numbers, from both lightning frequencies, in S4 and S6 scenarios, are from 3.1 to 3.7 higher than the BRAMS default. Even the lower bacterial concentrations (scenarios S2 and S3) produced 3 time higher number of flashes, compared to S5 scenario. This result is a function of the hydrometeors in each simulation. In conclusion, IN bacteria could affect directly the thunderstorm structure and lightning formation with many other microphysical implications.

\section{Introduction}

Over the past several years there has been a surge in novel research concerning the interaction of airborne microorganisms with atmospheric processes, as a complement to the existing well established and defined studies on inorganic ice nuclei (Pruppacher and Klett, 1997; Morris et al., 2011). There is growing evidence that bacteria and fungi, in particular, can influence atmospheric chemistry via the release of carbon and ions into the atmosphere (Elbert et al., 2007) and chemical transformation of atmospheric carbon sources (Deguillaume et al., 2008). Certain bacteria are also the most active ice nuclei found in the atmosphere and might have some influence on the formation of ice crystals in clouds (Möhler et al., 2007; Morris et al., 2004). Environmental sampling revealed that ice nucleation-active (INA) strains of the bacterium Pseudomonas syringae were enriched in rain and snowfall compared to other environmental sources where 
this bacterium is found (plants, water, epilithic biofilms) (Morris et al., 2008). In an experimental cloud chamber, this and other species of INA bacteria could induce condensation and subsequent freezing of cloud droplets (Möhler et al., 2008). Efforts to model the impact of INA microorganisms on the physical processes in clouds leading to precipitation have yielded somewhat conflicting results. Recent work by Hoose et al. (2010), in particular, suggests that primary biological aerosol particles in general have only a minor impact on cloud glaciation on a global scale relative to other heterogeneous ice nuclei in the atmosphere.

Microbiological as well as atmospheric physics approaches have suggested that certain types of plantassociated bacteria (such as $P$. syringae) and fungi (such as ice nucleation active Fusarium spp.) (Pouler et al., 1992) in the atmosphere could be important for rainfall formation (Morris et al., 2004; Bauer et al., 2003; Szyrmer and Zawadzki, 1997). The authors came to this conclusion because these bacteria produce a protein on their outer membrane that is one of the most active of the naturally-occurring ice nuclei (compounds capable of catalyzing the freezing of water - Jaenicke, 2005), and because freezing of cloud water is a critical step for rainfall over major parts of the earth (Sattler et al., 2001; Ariya and Amyot, 2004; Diehl et al., 2000 and, Hamilton and Lenton, 1998). These micro-organisms are widely distributed across the planet, multiply readily, survive airborne dissemination up to the clouds and fall out with precipitation and to act as ice nuclei (Pöschl et al., 2010 and Diel and Wurzler, 2010). If they play a catalyzing role in the formation of precipitation, they could have applications in drought mitigation.

Phillips et al. (2009) also wrote that the abundance of bacterial ice nuclei in the environment, their capacity to induce ice formation and their overall apparent link to the water cycle lead to the open question of whether emissions of such ice nucleating biogenic particles from their sources (plants in particular) can be modified by their own effects on clouds and atmospheric conditions, forming a weak feedback system, which is consistent with the proposal of Sands et al. (1982). If there is such a feedback system, there is also emerging evidence that it might have an impact on bacterial evolution in addition to an impact on atmospheric processes. In particular, results of a recent population genetics study suggest that ice nucleation activity is a driver for the evolution of plant pathogenicity in P. syringae (Morris et al., 2010). Elucidating the roles that ice nucleation can play in processes of the physical environment is therefore stimulating new directions of investigation on the subsequent impact of ice nucleation activity on the biology and evolution of microorganisms with this capacity.

According to Amato et al. (2005), the total bacterial density in clouds is about $3 \times 10^{4}$ cells $\mathrm{m}^{-3}$ of cloud volume $(1 \times$ $10^{5}$ cells ml $^{-1}$ of cloud water) based on direct visual counts of total cells. Most of the isolated micro-organisms, including 12 fungal and 17 bacterial strains, were described for the first time in atmospheric water by Amato and colleagues. Amato et al. (2007) found bacteria mainly in the genera Pseudomonas, Sphingomonas, Staphylococcus, Streptomyces, and Arthrobacter and fungi such as Cladosporium or Trametes. Additionally, Phillips et al. (2009) have shown in preliminary simulations, performed for a case of deep convection over Oklahoma, that certain concentrations of ice nuclei with activities similar to bacterial ice nuclei could influence significantly: (1) the average number and size of ice crystals in the clouds; (2) the horizontal cloud coverage in the free troposphere; and (3) precipitation and incident solar insolation at the surface, which influence rates of bacterial growth. There is currently very little data on the atmospheric concentration of biological ice nuclei. Approximations of the concentration of $P$. syringae, which seems to be the most frequently encountered and most active of the biological ice nuclei, can be made from ecological studies of its abundance in freshly fallen snow. The maximum concentration of $P$. syringae observed in fresh snow fall is $10^{5}$ bacteria $^{-1}$ and in rain is $10^{4}$ bacteria $^{-1}$ (Morris et al., 2008). All strains of $P$. syringae isolated from snow fall to date have measurable ice nucleation activity (Morris et al., 2008). Based on the reported ice nucleation activities in these samples (Morris et al., 2008) and the cumulative frequency profile of the most active ice nucleation active strain reported to date (Orser et al., 1985), about $10 \%$ of the cells of $P$. syringae would be active at $-8^{\circ} \mathrm{C}$ and nearly all of the cells would be active at $-12^{\circ} \mathrm{C}$. Their data indicates how the number of ice nuclei per cell changes with changing temperature. Additionally, Möhler et al. (2008) found maximum ice-active fractions of $10^{-4}$ for $P$. syringae and other bacterial species in the temperature range between -7 and $-11^{\circ} \mathrm{C}$. Direct observations of biological ice nuclei in freshly fallen snow fall have revealed at most 120 ice nuclei $1^{-1}$ of melt water active at $-7{ }^{\circ} \mathrm{C}$ (Christner et al., 2008) which also present a number range of DNA-containing cells from $1.5 \times 10^{4}$ to $5.4 \times 10^{6}$ cells per 1 . The snow analyzed in these studies might have accumulated ice nuclei from the atmosphere as it fell. Nevertheless, these values provide a realistic range of numbers of biological ice nuclei per volume of cloud water. Additionally, most of the inorganic ice nuclei are active only below $-12{ }^{\circ} \mathrm{C}$ (Pruppacher and Klett, 1997, Table 9.6 p. 319).

On the other hand, Levin et al. (2005) show simulations without ice-nucleating ability of the biological or mineral dust, but allowing the soluble component of the mixed aerosols to act as efficient giant cloud condensation nuclei $(\mathrm{CCN})$, enhancing the development of warm rain. In their simulations the rain amounts increased by as much as $37 \%$ compared to the case without giant $\mathrm{CCN}$. On the other hand, allowing the mineral dust particles to also act as efficient ice nuclei (IN) reduces the amount of rain on the ground compared to the case when they are inactive. Their simulations reveal that when the dust particles are active as both giant $\mathrm{CCN}$ and effective IN, the continental clouds become wider. 
One important role of ice formation in environmental processes is in the production of lightning. The main mechanism responsible for cloud electrification is the non-inductive mechanism, which involves rebounding collisions between graupel and ice crystals in the presence of supercooled liquid water (MacGorman and Rust, 1998). According to Mansell et al. (2005), the non-inductive charging schemes, which are dependent on the graupel rime accretion rate, tended to produce an initially inverted polarity charge structure and cloud to ground flashes. During the rebounding collisions, electric potential charge is transferred between the particles with opposite signs. Concerning the non-inductive mechanism as the main process responsible for cloud electrification, there are many observational or modelling studies such as Reynolds et al. (1957); Williams and Lhermitte (1983); Dye et al. (1989); Rutledge et al. (1992); Latham et al. (2007), among others. The amount of charge transferred depends on the particle sizes and their fall velocity, while the sign depends on the cloud temperature and supercooled liquid water content (e.g., Takahashi, 1978; Saunders et al., 1991, 2006; Pereyra et al., 2000; Takahashi and Miyawaki, 2002). Due to the equilibrium between vertical pressure gradient and gravitational force, the smaller (less dense) particles are carried aloft into higher regions of the cloud by its updrafts, while larger (denser) particles like hail and graupel are carried only to mid levels inside the cloud, creating major electric charged centers inside the cloud of opposite signs. Several charged centers can be produced according to the characteristics of the storm dynamics, which controls cloud vertical and horizontal motions, redistributing the charged ice hydrometeors vertically and horizontally. When the electric potential differences between these centers are strong enough to break up the dielectric breakdown of air, lightning is initiated trough an avalanche of electrons that can occur from cloud-to-ground (CG) or inside the clouds, i.e., intra-cloud (IC). In the case of CG lightning, the lightning channel formation is lead by stepped leaders (that creates a conducting path between charge centers) and then followed by one or multiple return strokes that traverse the channel moving electric charges and neutralizing the leaders (Rakov and Uman, 2003). As bacterial ice nuclei in the environment could lead to an increased number of ice crystals, an increase in the number of rebounding collisions between ice particles would be observed, which may increase the total amount of electric charge transferred and the charged centers, and which in turn would increase lightning activity in the cloud.

The impact on cloud electricity is also extended beyond the number of lightning discharges alone. Lightning is the largest non-anthropogenic source of $\mathrm{NO}_{2}$ and $\mathrm{NO}$ (together referred as $\mathrm{NO}_{\mathrm{x}}$ ) in the free troposphere. According to Schumann and Huntrieser (2007), the knowledge of the lightninginduced nitrogen oxides $\left(\mathrm{LNO}_{\mathrm{x}}\right)$ source is important for understanding and predicting the nitrogen oxides and ozone distributions in the troposphere. This knowledge is further required for the assessment of other important $\mathrm{NO}_{\mathrm{x}}$ sources for understanding the possible feedback between climate changes and lightning. $\mathrm{NO}_{\mathrm{x}}$ is an important trace gas in ozone chemistry and an increase in lightning frequency could increase lightning-generated $\mathrm{NO}_{\mathrm{x}}$ in the middle and upper troposphere, as well as the ozone concentrations. Ozone is the third most important greenhouse gas, playing a big role in radiative climate forcing that could be affected by changes in lightning production.

In this investigation, we used a high-resolution configuration of the Brazilian Regional Atmospheric Modeling System (BRAMS). The RAMS model utilizes the full set of nonhydrostatic, Reynolds-averaged primitive equations (Tripoli and Cotton, 1982). The Brazilian version of the RAMS is the result of changes incorporated by Brazilian users in recent years, which include a simple photochemical and a soil moisture scheme. Validation of the BRAMS for use in the Amazon region simulations is presented by Freitas et al. (2009). The cloud microphysics in BRAMS is described by Martins et al. (2009) based on Walko et al. (1995) and Meyers et al. (1997). Therefore, the main goal of this work is to evaluate the impact of the concentration of ice nucleation-active bacteria on cloud electricity, particularly flash rates, using BRAMS cloud modeling.

\section{Methodology}

\subsection{BRAMS modeling}

The numerical simulations were developed in order to investigate the effect of IN concentrations on the total amount of rainwater in the integrated vertical column and on rainfall. Homogeneous initializations were performed and simulations carried out for a time interval of $3 \mathrm{~h}$. Heating and wetting at the center of the grid were introduced after $10 \mathrm{~min}$ of simulation, mimicking a low level forcing in order to develop a convective cell. This low level forcing was applied according to Gonçalves et al. (2008). The chosen temperature and humidity profiles to initiate the model were taken from a radiosonde data sampled on 3 March 2003, which is typical for summertime at São Paulo City $\left(-23.59^{\circ} \mathrm{S}\right.$, $43.66^{\circ} \mathrm{W}$ ) (Fig. 1a). Figure 1b shows the radiosonde profile of the date 3 March. Figure 1c presents a weather radar image at 18:00 GMT, emphasizing a strong convective event exactly over São Paulo City. With the purpose of testing the sensitivity of microphysical parameters, the low level forcing was activated without topography, wind and surface. The objective of the simulations is to analyze the effect of the IN concentrations on the BRAMS modeled cloud properties, precipitation and lightning activity. Lightning frequency was inferred by the frozen ice mass fluxes and maximum updraft as described in the next section (2.3).

The simulated low level forcing was based on Walko et al. (1995) and produces complete development of both liquid and ice phases. The simulated domain had $60 \mathrm{~km}$ by $60 \mathrm{~km}$ 


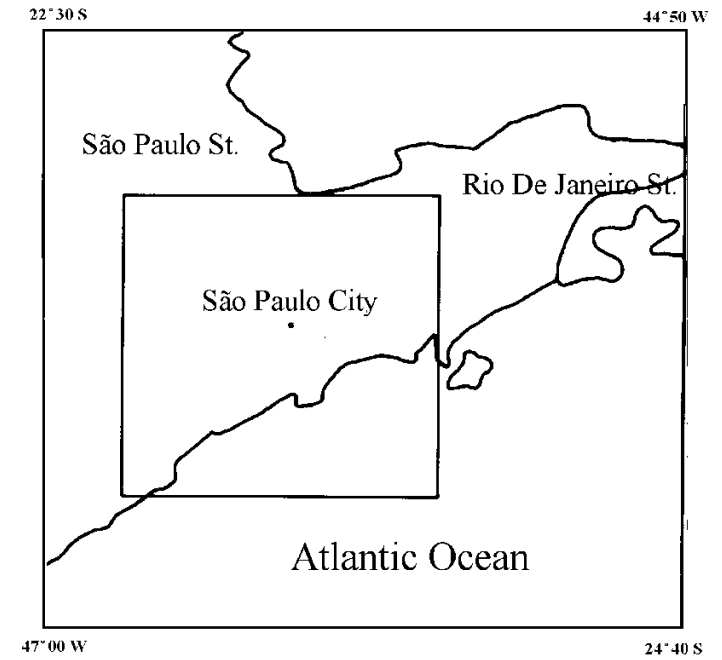

Fig. 1a. Study area where the radiosonde was launched.

horizontally with $500 \mathrm{~m}$ resolution and $20 \mathrm{~km}$ vertically with its resolution varying logarithmically, and the time step was $1 \mathrm{~s}$. A Rayleigh friction absorbing layer was used in the top of the model to prevent the reflection of gravity waves. The configuration of additional microphysical parameters in the numerical simulations was adjusted according to values suggested in empirical studies. Additional microphysical parameters suggested by Meyers et al. (1997) to the ice-crystal formation by primary nucleation processes (see Figs. 2, 3 and 4) and those suggested by Hallett and Mossop (1974) from experiments that showed splintering of supercooled droplets impacting the surface of riming ice particles. The other important parameter that directly impacts IN is the shape of the frequency distribution of their sizes. Previous studies have shown that the precipitation process is strongly affected by $\mathrm{CCN}$ concentrations changes (Martins et al., 2009) and also the shape parameter of the size distributions. In addition, the two parameters ( $\mathrm{CCN}$ and shape parameter) were related to each other (Martins and Silva Dias, 2009). Higher shape parameter decreased the spectral width of hydrometeor categories, including pristine ice. Although the numerical simulations were sensitive to specified microphysical parameters, the CCN concentration was assumed as $300 \mathrm{~cm}^{-3}$ and the shape parameter was set to 2 , which corresponds to relatively clear atmospheric conditions (Gonçalves et al., 2008). In these simulations, bacteria act only as IN as it follows in the next section. There are no species differences among $\mathrm{CCN}$ and IN concentrations.

Although the model has $1 \mathrm{~s}$ time step, we show the results for every $2 \mathrm{~min}$.

\subsection{Ice nucleation modeling}

Based on the model characteristics described above, six numerical experiments were run in order to analyze the effects

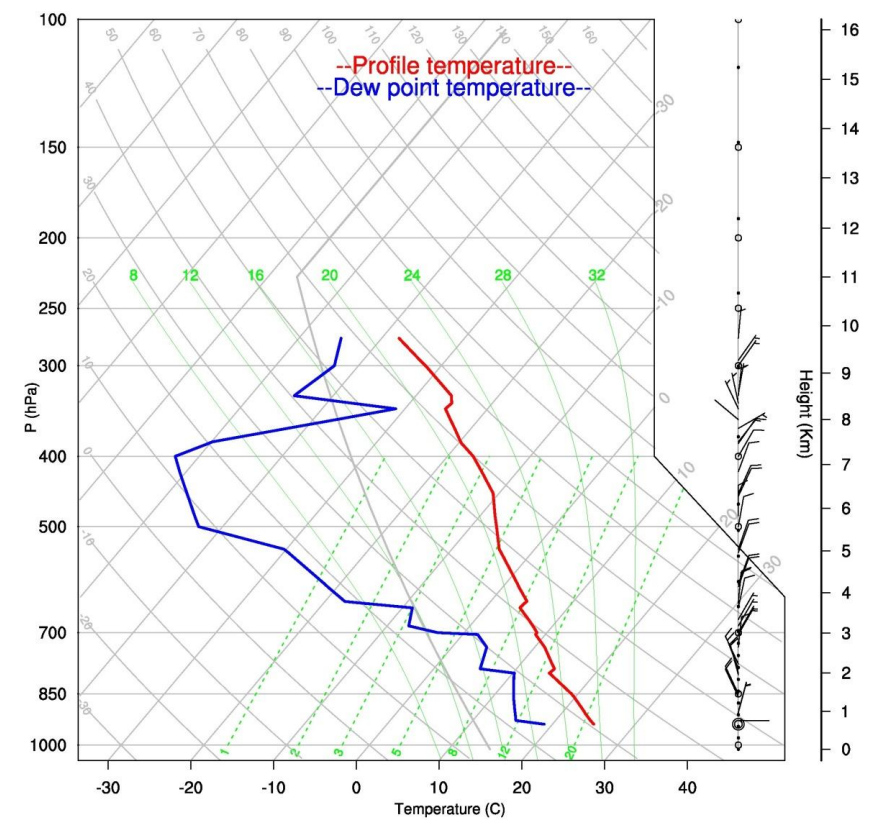

Fig. 1b. Radiosonde of 3 March 2003 at São Paulo airport (12:00 GMT), with temperature $\left({ }^{\circ} \mathrm{C}\right)$ and vapor ratio $\left(\mathrm{g} \mathrm{kg}^{-1}\right)$ vertical profiles.

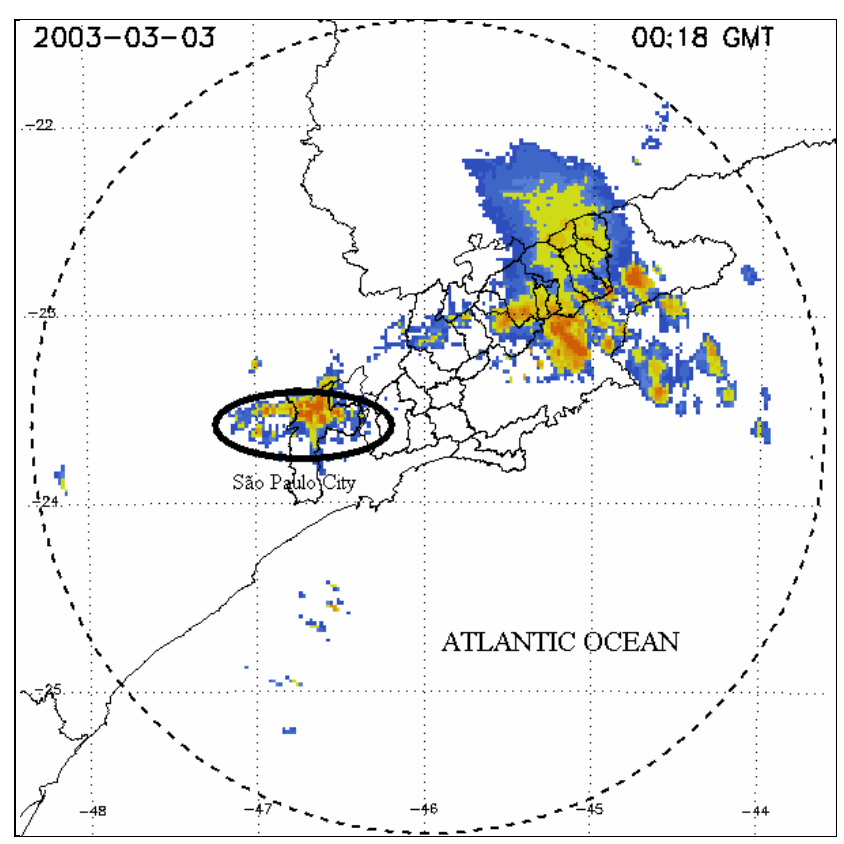

Fig. 1c. 3 March 2003 radar data at 18:00 GMT. Bluish and greenish colors mean $30 \mathrm{dBz}$ or less, or less than $5 \mathrm{~mm} \mathrm{~h}^{-1}$. Orange and reddish colors mean more than $40 \mathrm{dBz}$ and more than $20 \mathrm{~mm} \mathrm{~h}^{-1}$. The circled area correspond to the study area.

of IN concentrations on modeled cloud properties, precipitation and electrification. These simulations considered a series of ice nucleation parameterizations as shown in Fig. 2. 


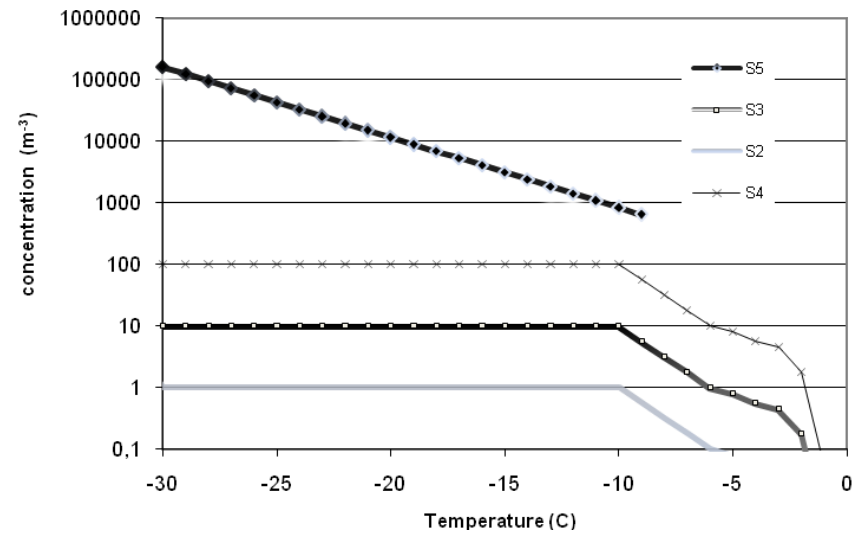

Fig. 2. Ice nuclei concentration profiles $\left(\mathrm{m}^{-3}\right)$, for different numerical scenarios involving the bacterium $P$. syringae $(\mathrm{S} 2, \mathrm{~S} 3, \mathrm{~S} 4)$ and BRAMS default parameterization (S5). Scenario S6 is performed summing up S4 and S5.

These simulations were also based on Orser et al. (1985) work to create the scenarios S2, S3, S4, as explained below, at temperatures warmer than $-10^{\circ} \mathrm{C}$. In the first numerical experiment (S1) the model was run in the homogeneous nucleating mode only. In this case, a small group of water molecules take on a crystal lattice structure due to random motions. After the initial crystal structure was established, it grew throughout the entire water droplet. The homogeneous nucleation followed the parameterization proposed by DeMott et al. (1994) and was applied in the temperature range from -50 to $-30^{\circ} \mathrm{C}$ (the value at $-50{ }^{\circ} \mathrm{C}$ was then applied to colder temperatures).

In the second numerical experiment ( $\mathrm{S} 2$ scenario), homogeneous nucleation occurred and IN concentration was assumed to be 100000 times less than the total population of bacteria observed by Amato et al. (2005) at a temperature range of -12 to $-2{ }^{\circ} \mathrm{C}$, where we adjust a polynomial equation between these two extremes. Only a fraction of total bacteria can act as IN (Morris et al., 2008), therefore it was set at 1 INA per $\mathrm{m}^{3}$ of cloud volume (see Fig. 2). As no observational data were available at temperatures colder than $-12{ }^{\circ} \mathrm{C}$, the IN concentration for $-10^{\circ} \mathrm{C}$ was used. Therefore, the number of nucleated ice crystals, at a certain time $(t)$, was also based on data for the abundance of $P$. syringae in precipitation (Morris et al., 2008). The P. syringae IN concentrations were assumed homogeneous over the whole model domain (vertical and horizontal) at the beginning of the simulation $(t=0)$ with no changes after the simulation started, there is no depletion of IN. The bacteria concentrations, in these scenarios, induced ice formation, as indicated in Fig. 2.

The third and fourth numerical experiments were the same as $\mathrm{S} 2$, but the initial IN concentration profiles were 10 (S3) and 100 (S4) times the value of S2. The last numerical scenario (S5) is the one that represents RAMS' default parame-
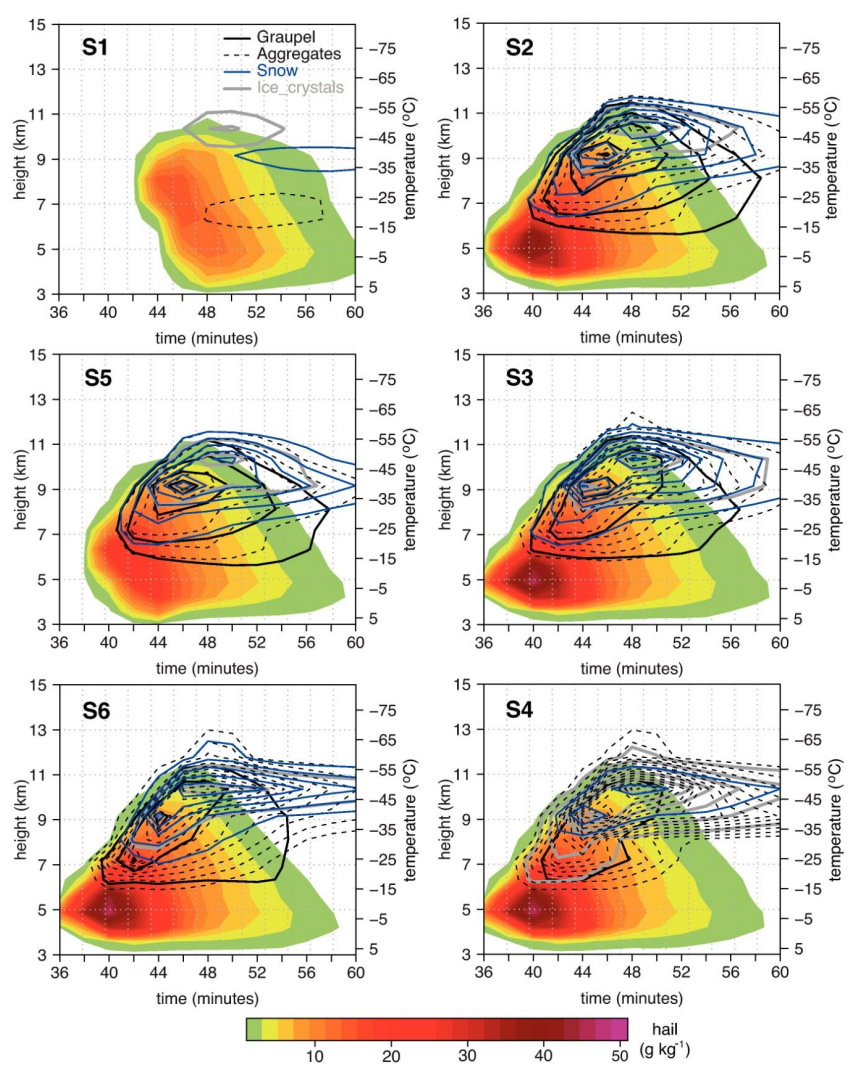

Fig. 3. Mixing ratio of ice hydrometeors (hail - shadded, and graupel, aggregates, snow and ice crystals - contours) for each simulation in the center of the domain, where the maximum values occur. Contour lines are mixing ratios for every $2 \mathrm{~g} \mathrm{~kg}^{-1}$.

terization, and it includes a variety of physical mechanisms: homogeneous nucleation (as in scenario S1); deposition nucleation and condensation-freezing nucleation (Meyers et al., 1997); contact freezing nucleation (Cotton et al., 1986). The sets of nucleation parameterization characteristics described above for each simulation are summarized in Table 1. S6 presents IN concentration as a combination of the S5 (RAMS default) and S4 scenario, with bacteria acting as IN. It must be pointed out that S5 and S6 scenarios based on the RAMS ice nucleation parameterization were used as reference cases. Secondary ice production, based on the Hallett-Mossop theory (Cotton et al., 1986), is included in all scenarios. It should be noted that the BRAMS default ice nucleation parameterization (S5) does not allow nucleation warmer than $-8^{\circ} \mathrm{C}$. The concentration of IN with bacteria follows exactly the IN concentration for normal RAMS and BRAMS defaults, i.e., there is no change in time by other processes as it is normally used for those models. 


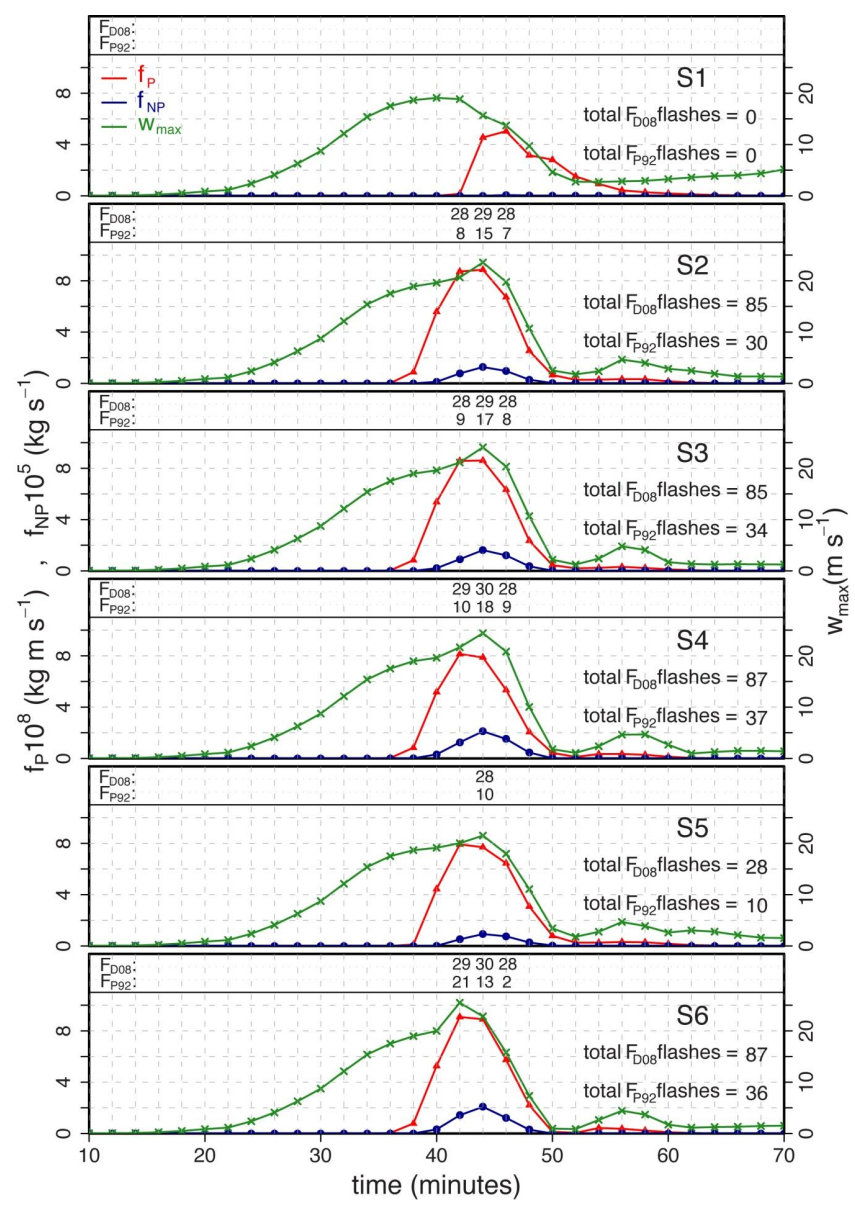

Fig. 4. Precipitable ice mass flux $\left(f_{\mathrm{P}}\right)$, non-precipitable ice mass flux $\left(f_{\mathrm{NP}}\right)$ and maximum cloud updraft $\left(w_{\max }\right)$ for every $\Delta t=$ 2 min for each simulation (S1, S2, S3, S4, S5 and S6). Numbers at the top of each panel correspond to the number of estimated lightning flashes at the respective simulation time $t(F \times \Delta t)$.

\subsection{Cloud electrification: total flash estimated from ice mass fluxes and maximum updraft}

Simulation of cloud electric activity is a challenge. The noninductive charge transfer is well accepted as the main mechanism for cloud electrification and it is reasonably easy to compute numerically, depending only on ice particle collisions, a task already carried by cloud resolving models. However, the amount of charge transferred during each collision is parameterized in a few laboratory studies (Takahashi, 1978; Saunders et al., 1991; Pereyra et al., 2000; Takahashi and Miyawaki, 2002; Saunders et al., 2006) and it is proportional to the size difference between the ice particles, the temperature inside the cloud, and cloud updraft. These laboratory studies show substantial differences in their methodology and results (Saunders et al., 2006) which can lead to different electrical cloud structures and lightning flash rates of simulated thunderstorms (Helsdon Jr. et al., 2001; Mansell et al., 2005; Altaratz et al., 2005; Barthe and Pinty, 2007; Albrecht, 2008; Albrecht et al., 2008). Also, the electrical charge neutralization produced by the lightning channels is poorly understood and has a high computational cost. Studies of electrical charge transfer and lightning propagation remain under investigation.

Several relationships between lighting flash rate and observed cloud parameters have been reported in the literature. For example, Williams (1985) showed a fifth power relationship between storm cloud height and flash rate $(F)$, and Price and Rind (1992) modified this relationship using the maximum cloud updraft $\left(w_{\max }\right)$ to take into account the storm dynamics:

$F=5 \times 10^{-6} \times w_{\max }^{k}$

where $k$ was derived from satellite data and equals to 4.5 for continental deep convection, for $F$ in $\mathrm{fl} \mathrm{min}^{-1}$ and $w_{\max }$ in $\mathrm{m} \mathrm{s}^{-1}$. The fluxes $F_{\mathrm{P} 92}$ and $F_{\mathrm{D} 08}$ will be defined later in the text. Hereinafter, this relationship (Eq. 1) is called P92. This relationship is based on scaling arguments previously derived by Vonnegut (1963) and simplified by Williams (1985), where the authors assume that the magnitude of the updraft is positively correlated to the cloud top height. A fifth power relationship to the storm cloud depth was also reported by Yoshida et al. (2009), and Boccippio et al. (2002) showed that the flash rate-updraft relationship suggests a higher power. Petersen et al. (2005) found a linear relationship between total lightning flash rate and ice water path, independent of the regime (land, ocean or coastal zones). Likewise, based on the charging zone concept, several studies have shown strong correlation between the total (intra-cloud and cloudto-ground lightning) flash rate and the precipitable and nonprecipitable ice masses (Blyth et al., 2001; Latham et al., 2004, 2007; Deierling et al., 2008). The terms precipitable and non-precipitable ice masses are associated with the hydrometeor types likely to precipitate or not, relative to the convective core updraft, i.e., denser particles like hail and graupel can precipitate over the convective core and are defined as precipitable ice mass, while snowflakes and ice crystals cannot and are therefore defined as non-precipitable ice mass. Blyth et al. (2001) have shown simple calculations of this correlation by yielding the prediction that the total lightning (intracloud and cloud-to-ground) frequency $F$, flashes per minute (fl $\min ^{-1}$ ), was roughly linearly proportional to the product of downward moving ice precipitation (precipitable ice mass - graupel and hail - flux, $f_{\mathrm{P}}$ ) and upward moving crystals (non-precipitable ice mass $-f_{\mathrm{NP}}$ ) in the convective core of thunderstorms:

$F=C \cdot f_{\mathrm{P}} \cdot f_{\mathrm{NP}}$

where $C$ is constant. Latham et al. $(2004,2007)$ have extended the relationship on Eq. (2) to several studies in the literature, and restate the correlation between $F, f_{\mathrm{P}}$ and $f_{\mathrm{NP}}$.

Deierling et al. (2008) correlated total lightning frequency (from the Northern Alabama Lightning Mapping 
Table 1. Type of nucleation considered in each simulation.

\begin{tabular}{cccccl}
\hline $\begin{array}{l}\text { Type of ice } \\
\text { nucleation/ } \\
\text { Simulation }\end{array}$ & Homogeneous & Deposition & $\begin{array}{l}\text { Condensation } \\
\text { and Freezing }\end{array}$ & $\begin{array}{c}\text { Contact and } \\
\text { Freezing }\end{array}$ & $\begin{array}{l}\text { Bacterial-concentrations } \\
\text { per cloud volume } \\
\left(\mathrm{m}^{3}\right)\end{array}$ \\
\hline S1 & Yes & No & No & No & No \\
S2 & Yes & No & No & No & Yes, $w / 1$ \\
S3 & Yes & No & No & No & Yes, $w / 10$ \\
S4 & Yes & No & No & No & Yes, $w / 10^{2}$ \\
S5 & Yes & Yes & Yes & Yes & No \\
S6 & Yes & Yes & Yes & Yes & Yes, $w / 10^{2}$ \\
\hline
\end{tabular}

Array (NALMA) and two field experiments) to ice mass fluxes derived from dual-polarimetric Doppler radar data using Eq. (2). The thunderstorms analyzed by these authors (11 storms in total) comprehended severe storms with multicellular characteristics, moderate intensity ordinary thunderstorms, single cell thunderstorms, and supercell thunderstorms. Deierling et al. (2008) then found that the Eq. (2) type relationship between total lightning frequency $F$ and the product of ice mass fluxes $\left(f_{\mathrm{P}} \cdot f_{\mathrm{NP}}\right)$ for all 11 storms investigated has the form:

$F=9.0 \times 10^{-15} \cdot f_{\mathrm{P}} \cdot f_{\mathrm{NP}}+13.4$

where $F$ is in flashes per minute $\left(\mathrm{fl} \mathrm{min}{ }^{-1}\right) ; f_{\mathrm{P}}$ in $\mathrm{kg} \mathrm{m} \mathrm{s}^{-1}$; and $f_{\mathrm{NP}}$ in $\mathrm{kg} \mathrm{s}^{-1}$. Hereinafter, this relationship (Eq. 3) is called D08; $f_{\mathrm{P}}$ is the product of the precipitable ice mass $\left(m_{\mathrm{P}}\right)$ (in $\mathrm{kg}$ ) and the terminal fall speed of precipitable hydrometeors $\left(v_{\mathrm{t}}\right)$ :

$f_{\mathrm{P}}=m_{\mathrm{P}} v_{\mathrm{t}}$

The non-precipitable ice mass flux $f_{\mathrm{NP}}$ would be the product of non-precipitable ice mass $m_{\mathrm{NP}}$ and the storm updraft $w$ $\left(f_{\mathrm{NP}}=m_{\mathrm{NP}} \cdot w\right)$, but as $w$ could not be inferred directly from Doppler radar, Deierling et al. (2008) assumed that the vertical change in the updraft velocity $w$ is proportional to the horizontal divergence through the anelastic continuity equation $\left.\nabla_{\mathrm{H}} \rho_{0} \boldsymbol{V}=\partial\left(w \rho_{0}\right) / \partial z\right)$, so that

$f_{\mathrm{NP}}=m_{\mathrm{NP}} \partial w / \partial z=m_{\mathrm{NP}}\left(\nabla_{\mathrm{H}} \rho_{0} \boldsymbol{V}\right)$.

Deierling et al. (2008) also derived relationships between total lightning flash rates and precipitable and non-precipitable ice mass fluxes alone, as well as precipitable and nonprecipitable ice masses alone.

Barthe et al. (2010) examined several of these empirical lightning and storm parameters relationships on a cloud resolved model. These authors compared the observed and simulated lightning flash rates from six model parameters: precipitable ice mass, ice water path, precipitable and nonprecipitable ice mass fluxes product, updraft volume, maximum vertical velocity, and cloud top height. They have scaled the previously relationships using the observations of two thunderstorms (one sever and one ordinary), and found that maximum updraft was the best parameter for the severe storm flash rate proxy, while the cloud top height was the best one for the ordinary storm. For both storms, the ice mass flux product captured the thunderstorm electrical activity trend but overestimated the magnitude.

In our simulation with BRAMS, we estimate the total flash produced for each individual convective cell by P92 and D08 relationships for every $2 \min (\Delta t=2 \mathrm{~min})$. For P92, $k=4.5$ was used and $F_{\mathrm{P} 92}$ was calculated only when both precipitable and non-precipitable ice masses were observed. For D08, we also compute $F_{\mathrm{D} 08}$ only when both precipitable and non-precipitable ice masses were observed and $f_{\mathrm{P}}$ and $f_{\mathrm{NP}}$ are estimated at each time step using Eqs. (4) and (5), respectively. The precipitable hydrometeors in BRAMS are hail and graupel, and the rest of ice species are non-precipitable, i.e., aggregates, snow, and pristine crystals. Therefore, at each time step hail mass and graupel mass were multiplied by their respective terminal fall speed in each grid point and then summed over the storm volume to obtain $f_{\mathrm{P}}$. Analogously, the sum of aggregates, snow and pristine crystal masses were multiplied by the horizontal divergence in each grid point and then summed over the storm volume to obtain $f_{\mathrm{NP}}$. Only grid points inside the storm updraft, above the level of $-5^{\circ} \mathrm{C}$, were considered $\left(w>0 \mathrm{~m} \mathrm{~s}^{-1}\right)$, and in the case of $f_{\mathrm{NP}}$, only the ice particles where their terminal fall speed was smaller than the updraft were considered (Barthe and Pinty, 2007; Deierling et al., 2008).

The resulting total number of flashes using $\mathrm{P} 92\left(F_{\mathrm{P} 92} \times \Delta t\right)$ and $\mathrm{D} 08\left(F_{\mathrm{D} 08} \times \Delta t\right)$ relationships are presented in Sect. 3.2.

\section{Results and discussions}

\section{Impact on cloud properties and precipitation}

The cloud microphysics simulated by each scenario of Table 1 is summarized in Table 2. This table shows the hydrometeor paths for all types (peak values), as well as rain variables at ground level. These values are the peak values which occur in the center of the computational domain due to the idealized setup, the simulated cloud is symmetric in 
Table 2. Peak water path $\left(\mathrm{g} \mathrm{m}^{-2}\right)$ of hydrometeors for all simulations. These values are the maximum values in one grid cell of the model domain during the duration $(3 \mathrm{~h})$ of the simulations. Values in parentheses are the percentage deviation from the simulation with no IN (S1, i.e., percentage deviation $=v_{\mathrm{S} y} / v_{\mathrm{S} 1} \cdot 100-100 \%$, where $v$ is the variable and $y$ is the simulation type).

\begin{tabular}{|c|c|c|c|c|c|c|}
\hline & $\mathrm{S} 1$ & $\mathrm{~S} 2$ & S3 & S4 & S5 & S6 \\
\hline Cloud water & 41922 & $\begin{array}{l}42066 \\
(+0.3 \%)\end{array}$ & $\begin{array}{l}41965 \\
(+0.1 \%)\end{array}$ & $\begin{array}{l}41645 \\
(-0.7 \%)\end{array}$ & $\begin{array}{l}42085 \\
(+0.4 \%)\end{array}$ & $\begin{array}{l}41453 \\
(-1.1 \%)\end{array}$ \\
\hline Rain & 9092 & $\begin{array}{l}8398 \\
(-8 \%)\end{array}$ & $\begin{array}{l}8370 \\
(-8 \%)\end{array}$ & $\begin{array}{l}8320 \\
(-8 \%)\end{array}$ & $\begin{array}{l}8618 \\
(-5 \%)\end{array}$ & $\begin{array}{l}8355 \\
(-8 \%)\end{array}$ \\
\hline Hail & 380 & $\begin{array}{l}752 \\
(+98 \%)\end{array}$ & $\begin{array}{l}775 \\
(+104 \%)\end{array}$ & $\begin{array}{l}758 \\
(+100 \%)\end{array}$ & $\begin{array}{l}544 \\
(+43 \%)\end{array}$ & $\begin{array}{l}774 \\
(+104 \%)\end{array}$ \\
\hline Graupel & 29 & $\begin{array}{l}225 \\
(+675 \%)\end{array}$ & $\begin{array}{l}164 \\
(+465 \%)\end{array}$ & $\begin{array}{l}88 \\
(+203 \%)\end{array}$ & $\begin{array}{l}190 \\
(+555 \%)\end{array}$ & $\begin{array}{l}149 \\
(+414 \%)\end{array}$ \\
\hline Aggregates & 41 & $\begin{array}{l}308 \\
(+644 \%)\end{array}$ & $\begin{array}{l}372 \\
(798 \%)\end{array}$ & $\begin{array}{l}565 \\
(+1265 \%)\end{array}$ & $\begin{array}{l}223 \\
(+437 \%)\end{array}$ & $\begin{array}{l}465 \\
(+1022 \%)\end{array}$ \\
\hline Snow & 68 & $\begin{array}{l}210 \\
(+211 \%)\end{array}$ & $\begin{array}{l}235 \\
(+248 \%)\end{array}$ & $\begin{array}{l}90 \\
(+34 \%)\end{array}$ & $\begin{array}{l}199 \\
(+194 \%)\end{array}$ & $\begin{array}{l}210 \\
(+210 \%)\end{array}$ \\
\hline Ice crystal & 43 & $\begin{array}{l}83 \\
(+93 \%)\end{array}$ & $\begin{array}{l}110 \\
(+155 \%)\end{array}$ & $\begin{array}{l}230 \\
(+433 \%)\end{array}$ & $\begin{array}{l}85 \\
(+96 \%)\end{array}$ & $\begin{array}{l}107 \\
(+147 \%)\end{array}$ \\
\hline Precipitable ice & 409 & $\begin{array}{l}977 \\
(+139 \%)\end{array}$ & $\begin{array}{l}940 \\
(+130 \%)\end{array}$ & $\begin{array}{l}846 \\
(+107 \%)\end{array}$ & $\begin{array}{l}734 \\
(+80 \%)\end{array}$ & $\begin{array}{l}924 \\
(+126 \%)\end{array}$ \\
\hline Non-precipitable ice & 152 & $\begin{array}{l}601 \\
(+295 \%)\end{array}$ & $\begin{array}{l}717 \\
(+371 \%)\end{array}$ & $\begin{array}{l}886 \\
(+482 \%)\end{array}$ & $\begin{array}{l}506 \\
(+233 \%)\end{array}$ & $\begin{array}{l}781 \\
(+413 \%)\end{array}$ \\
\hline
\end{tabular}

the horizontal directions. It can be seen in Table 2 that the inclusion of IN caused a small impact in total liquid water (cloud water and rain) among the simulations. The simulation with no IN (S1) produced $41922 \mathrm{~g} \mathrm{~m}^{-2}$ of cloud water and $9092 \mathrm{~g} \mathrm{~m}^{-2}$ (or $9 \mathrm{~mm}$ ) of rain, which is less than a unit of percentage higher than those with IN (S2, S3, S4, S5) for cloud water and a few units of percentage lower for rain. It must be clarified that high cloud water result is due to forced simulation, not a real one. Among the simulations with IN, only S4 and S6 presented a tendency to decrease the total cloud water, and all those with IN presented a tendency to decrease the total amount of rain integrated in the column $(-8 \%)$. The last result agrees with Levin et al. (2005), who also found rain reduction on the ground. It must also be noted that the observed rainfall amount was $23 \mathrm{~mm}$ near the center grid, close to the simulated rainfall values of 8 to $9 \mathrm{~mm}$.

However, the impact on the total ice production is very significant. The simulations with $P$. syringae as ice nuclei (S2, S3 and S4) produced total hail path on the order of $750 \mathrm{~g} \mathrm{~m}^{-2}$ which is $\sim 100 \%$ greater than the one produced by $\mathrm{S} 1\left(380 \mathrm{~g} \mathrm{~m}^{-2}\right)$. The default BRAMS simulation (S5) also produced more hail than the $\mathrm{S} 1$ simulation $\left(544 \mathrm{~g} \mathrm{~m}^{-2}\right.$, $43 \%$ more). The simulation with a lower concentration of P. syringae (S2) generated $675 \%$ more graupel than S1, and $555 \%$ more than S5. The simulation with an intermediate concentration of $P$. syringae (S3) was the one that produced more snow, and the simulation with the maximum amount of $P$. syringae (S4) produced many more aggregates and ice crystals (565 and $230 \mathrm{~g} \mathrm{~m}^{-2}$, respectively) than S1 (41 and $43 \mathrm{~g} \mathrm{~m}^{-2}$, respectively) and the other simulations. More aggregates and ice crystals, as well as graupel and hail, are essential for rebounding ice collisions and therefore for electric charge transfer and lightning production, as described in the next section (3.2).

To show the temporal evolution of the ice hydrometeors of each simulation, Fig. 3 shows the total mixing ratio of hail, graupel, aggregates, snow and ice crystals for each simulation, integrated over the horizontal extent of the cloud at each 2-min model output. As shown in Table 2, Fig. 3 also shows that there are significant differences in total hydrometeor mixing ratios among the simulations with no IN (S1) and those with IN (S2, S3, S4, S5), but with temporal details. Table 3 gives the maximum values of these variables and the time when these maximums occurred. The direct impact of IN is on the concentration of pristine ice crystals, which then indirectly impacts the production of other hydrometeors. Therefore, S1 simulation produced the fewest ice hydrometeors amounts of all the simulations as no IN was available for nucleation and the only source of ice crystals was due to homogeneous nucleation. This feature also affected the temporal evolution of the cloud: S1 produced significant amounts of frozen hydrometeors (mixing ratios 
Table 3. Maximum of ice hydrometeor mixing ratio $\left(\mathrm{g} \mathrm{kg}^{-1}\right)$ for each simulation, where the values in parentheses are the time in minutes when the maximum occurred.

\begin{tabular}{lrrrrrr}
\hline & S1 & S2 & S3 & S4 & S5 & S6 \\
\hline Hail & $15(t=46)$ & $42(t=40)$ & $46(t=40)$ & $47(t=40)$ & $26(t=42)$ & $46(t=40)$ \\
Graupel & $1.2(t=48)$ & $10(t=46)$ & $6.8(t=46)$ & $3.2(t=46)$ & $9.2(t=46)$ & $6.6(t=44)$ \\
Aggregates & $3.6(t=52)$ & $18(t=46)$ & $22(t=48)$ & $33(t=48)$ & $13(t=46)$ & $26(t=48)$ \\
Snow & $2.9(t=58)$ & $12(t=46)$ & $14(t=48)$ & $5.5(t=44)$ & $13(t=46)$ & $12(t=46)$ \\
Ice Crystal & $4.3(t=50)$ & $5.1(t=48)$ & $4.7(t=50)$ & $13(t=44)$ & $4.6(t=48)$ & $4.4(t=48)$ \\
\hline
\end{tabular}

greater than $2 \mathrm{~g} \mathrm{~kg}^{-1}$ ) several minutes later than the other ones, as shown in Fig. 3. Ice crystals by homogeneous freezing in $\mathrm{S} 1$ had its peak $\left(4.3 \mathrm{~g} \mathrm{~kg}^{-1}\right)$ at $\sim 10.5 \mathrm{~km}$ altitude after $50 \mathrm{~min}$ of simulation. The altitude of the peak of ice crystal production was constant in all other simulations and the time when the peak occurred was 2-6 min earlier, except for S3 which occurred at the same time as in S1. The addition of IN tended to generate two peaks of ice crystals: the one at $10.5 \mathrm{~km}$ by homogeneous nucleation, and a second one at $\sim 9 \mathrm{~km}$ due to heterogeneous nucleation. In simulations S2 and S5 this second peak is not apparent but an elongated branch of $2 \mathrm{~g} \mathrm{~kg}^{-1}$ of ice crystals is observed downward of $10 \mathrm{~km}$ after 42 to 48 min of simulation in S2 to S5. In S3 and $\mathrm{S} 4$ a second peak of $\sim 4$ and $\sim 12 \mathrm{~g} \mathrm{~kg}^{-1}$, respectively, clearly developed at $t=44$ min due to more IN.

Greater amounts of ice crystals in S2 to S5 impacted the production of other ice species, first due to rimming and accretion, generating greater amounts of aggregates $\left(\sim 2 \mathrm{~g} \mathrm{~kg}^{-1}\right)$ as soon as 40 min of simulation for $\mathrm{S} 3$ and $\mathrm{S} 4$, and 2 min later for S2 and S5. Aggregates also presented two peaks in S2 to S5, at the same heights as the ice crystal peaks due to the conversion of ice crystals into aggregates by rimming, accreation and auto-conversion. S5 presented the highest aggregate peak with $33 \mathrm{~g} \mathrm{~kg}^{-1}$ at $t=48 \mathrm{~min}$. Snow also presented the same behavior in time and vertical space as aggregates: maximums of snow were produced at $\sim 9$ and $10.5 \mathrm{~km}$ of height also due to rimming, accretion and autoconversion of ice crystals, except for S5 which presented a single peak at $\sim 9 \mathrm{~km}$ of half $\left(5.7 \mathrm{~g} \mathrm{~kg}^{-1}\right)$ of the intensity of the other IN simulations $\left(\sim 13 \mathrm{~g} \mathrm{~kg}^{-1}\right)$. This behavior might be because ice crystals would accreate and rime in higher rates, as well as auto-convert, in an environment with greater amounts of ice crystals, forming aggregates more quicker than in environments with fewer ice crystals.

The behavior of ice crystals, snow, and aggregates described above was also translated into greater amounts of hail and graupel. S1 resulted in a hail maximum of $15 \mathrm{~g} \mathrm{~kg}^{-1}$ at $t=46 \mathrm{~min}$, and a graupel maximum of only $1.2 \mathrm{~g} \mathrm{~kg}^{-1}$ at $t=48 \mathrm{~min}$, while the bacterial simulations (S2, S3, S4) produced three times more hail $\left(\sim 45 \mathrm{~g} \mathrm{~kg}^{-1}\right) 8 \mathrm{~min}$ earlier. The production of graupel by S2, S3 and S4 was also higher than in $\mathrm{S} 1$ but decreased as the $P$. syringae concentration increased, giving place to the production of aggregates. The ag- gregates increased as the $P$. syringae concentration increased with a maximum of $33 \mathrm{~g} \mathrm{~kg}^{-1}$ at $t=48 \mathrm{~min}$ for $\mathrm{S} 4,22 \mathrm{~g} \mathrm{~kg}^{-1}$ at $t=48 \mathrm{~min}$, and $18 \mathrm{~g} \mathrm{~kg}^{-1}$ at $t=46 \mathrm{~min}$, as shown in Table 3 and Fig. 3.

Scenario S6, presenting the BRAMS default scenario (S5) plus S4 (the highest bacteria concentration), displays similar results as S4. Some of the hydrometeors presents even higher concentrations (see Table 2), compared to the previous simulations. However, the precipitable ice shows a decrease of less than $5 \%$ compared to S4 simulation. Therefore, it can be inferred from the above results that even a smaller concentrations of IN, at warmer temperatures, would accelerate the process of generation of hail and aggregates. This acceleration would be due to higher rates of accretion and rimming, and then auto-conversion, which quickly transform graupel and snow into hail and aggregates (respectively), decreasing the amount of graupel and snow inside the cloud. The next section shows how these changes in ice species affect cloud electrification.

\section{Impact on cloud electrification}

As shown in Sect. 2.2, the amount of precipitable ice (graupel and hail) and non-precipitable ice (aggregates, snow and ice crystals), as well as updraft, are key ingredients for cloud electrification and lightning production. Table 2 shows that $P$. syringae simulations produced greater amounts of both total precipitable and non-precipitable ice than S1 and S5. The highest total precipitable ice was observed in S3 with $940 \mathrm{~g} \mathrm{~m}^{-2}$, but the other IN simulations had comparable values. In the case of total non-precipitable mass, S4 produced the greatest amount $\left(886 \mathrm{~g} \mathrm{~m}^{-2}\right)$, followed by S3, S2, and then S5, with not so comparable values $(717,601$, and $506 \mathrm{~g} \mathrm{~m}^{-2}$, respectively).

However, the strength of the updraft also controls cloud electrification. Stronger updrafts can happen at the same time as high generation of precipitable and non-precipitable ice to efficiently promote rebounding collisions between these species to transfer electric charges. Therefore, Fig. 4 shows the precipitable ice mass flux $\left(f_{\mathrm{P}}\right)$, non-precipitable ice mass flux $\left(f_{\mathrm{NP}}\right)$ and maximum cloud updraft $\left(w_{\max }\right)$ for each $2 \mathrm{~min}$ of simulation. Also, Table 4 shows the maximum value of these variables during the whole simulation. It can be seen 
Table 4. Maximum precipitable ice mass flux $\left(f_{\mathrm{P}}\right)$, non-precipitable ice mass flux $\left(f_{\mathrm{NP}}\right)$, and cloud updraft $(w)$, as well as the total estimated number of lightning flashes for each simulation. Numbers in parentheses indicate the time step when the maximum occurred.

\begin{tabular}{llllll}
\hline & $\begin{array}{l}\text { maximum } f_{\mathrm{P}} \\
\left(\mathrm{kg} \mathrm{m} \mathrm{s}^{-1}\right)\end{array}$ & $\begin{array}{l}\operatorname{maximum} f_{\mathrm{NP}} \\
\left(\mathrm{kg} \mathrm{s}^{-1}\right)\end{array}$ & $\begin{array}{l}w_{\max } \\
\left(\mathrm{m} \mathrm{s}^{-1}\right)\end{array}$ & $\begin{array}{l}\text { Total number } \\
\text { of flashes } \\
\text { estimated } \\
\text { by D08 }\end{array}$ & $\begin{array}{l}\text { Total number } \\
\text { of flashes } \\
\text { estimated } \\
\text { by P92 }\end{array}$ \\
\hline S1 & $5.04 \times 10^{8}\left(t=46^{*}\right)$ & $0.065 \times 10^{5}\left(t=46^{*}\right)$ & $19.1\left(t=40^{*}\right)$ & 0 & 0 \\
S2 & $8.86 \times 10^{8}(t=44)$ & $1.27 \times 10^{5}(t=44)$ & $23.6(t=44)$ & 85 & 30 \\
S3 & $8.60 \times 10^{8}(t=44)$ & $1.62 \times 10^{5}(t=44)$ & $24.1(t=44)$ & 85 & 34 \\
S4 & $8.14 \times 10^{8}(t=42)$ & $2.11 \times 10^{5}(t=44)$ & $25.2(t=45)$ & 87 & 37 \\
S5 & $7.92 \times 10^{8}(t=42)$ & $0.925 \times 10^{5}(t=44)$ & $21.5(t=44)$ & 28 & 10 \\
S6 & $9.08 \times 10^{8}(t=42)$ & $2.08 \times 10^{5}(t=44)$ & $25.5(t=42)$ & 87 & 36 \\
\hline
\end{tabular}

* All time steps are given in minutes.

that simulations with IN developed stronger updrafts, with the one with most ice production (S4), and therefore greatest latent heat release, having the strongest $w_{\max }\left(25.2 \mathrm{~m} \mathrm{~s}^{-1}\right)$ among S2, S3 and S4. Therefore, the lighting flashes estimated only by $w_{\max }(\mathrm{P} 92)$ produced more total number of flashes for these simulations that considered bacterial IN: 30 , 34, 37 and 36 flashes for S2, S3, S4 and S6, respectively. Figure 4 shows that these same simulations produced lightning during $4 \mathrm{~min}$ of simulation (from $t=42$ to $t=46 \mathrm{~min}$ ). $\mathrm{S} 2, \mathrm{~S} 3$ and S4 produced the maximum updraft at $t=44 \mathrm{~min}$, while S6 produced 2 min earlier with the strongest $w_{\max }$ $\left(25.5 \mathrm{~m} \mathrm{~s}^{-1}\right)$ and the larger number of flashes at an individual model output (21 flashes at $t=42 \mathrm{~min}$ ). S4 kept slightly higher values of $w_{\max }$ throughout the simulation, which resulted in a constant lightning flash production (10, 18 and 9 flashes) and then relatively larger total number of flashes (37). S5 generated flashes only at $t=44 \mathrm{~min}$ (28 flashes), while S1 did not present any flashes. Thereby, lightning flashes by P92 were produced only when $w_{\max }$ was greater than $20 \mathrm{~m} \mathrm{~s}^{-1}$.

For D08 relationship, it can be seen that the simulation with no ice nuclei (S1) did not produce lightning because of the very small production of non-precipitable ice mass flux, $6 \times 10^{3} \mathrm{~kg} \mathrm{~s}^{-1}$ (Fig. 4 and Table 3), compared to IN simulations that produced 3 orders of magnitude greater than S1. The low production of $f_{\mathrm{NP}}$ led to a low production of precipitable ice particles (e.g., graupel and hail) by rimming and auto-conversion processes as shown in Sect. 3.1. This implied a $36 \%$ smaller $f_{\mathrm{P}}$ in $\mathrm{S} 1\left(5.04 \times 10^{8} \mathrm{~kg} \mathrm{~m} \mathrm{~s}^{-1}\right)$ than the control run (S5, BRAMS default) $\left(7.92 \times 10^{8} \mathrm{~kg} \mathrm{~m} \mathrm{~s}^{-1}\right)$, as the maximum updrafts are similar in S1 and S5 (Fig. 3 and Table 4), producing 28 flashes in S5. When P. syringae ice nuclei were included in S2, S3, S4 the production of ice crystals increased greatly, generating 85,85 and 87 flashes, respectively. S6 simulation, although, presents same amount of flash of S4, 87 flashes in total (Table 4), approximately 3 times higher than BRAMS simulation (S5). Consequently, the high number of IN, from BRAMS default, acting below $-8^{\circ} \mathrm{C}$, plays a secondary role.

As P92, D08 only showed flash production at $t=44 \mathrm{~min}$ in S5, and from $t=42$ to $t=46 \mathrm{~min}$ for S2, S3, S4 and S6. This result highlights the importance of $w_{\max }$ lightning production. D08 produced $\sim 2.5$ more lightning flashes than P92 for all simulations. This suggests that both P92 and D08 are suitable for lightning parameterizations, but their relationships might need to be rescaled for the type of thunderstorm simulated here. Barthe et al. (2010) showed the need for scaling several lightning-cloud parameters relations when applying them to numerical cloud model. They showed that varying model spatial resolution produced significant variation among the simulated storm parameters (precipitable ice mass, ice water path, precipitable and non-precipitable ice mass fluxes product, updraft volume, maximum vertical velocity, and cloud top height), with the smallest variation for cloud top height $(6 \%)$ and the largest for precipitable and non-precipitable ice mass fluxes (59\%). Barthe et al. (2010) showed that this fact impacts greatly the lightning estimation for weak thunderstorms (less than $10 \mathrm{fl} \mathrm{min}^{-1}$ ) from storm parameters based on dynamical parameters, such as mass fluxes. They also showed that P92 predicts the magnitude of lightning flash rate very well, but do not predict the observed trends. D08 on the other hand captured the electrical activity but missed the magnitude. Unfortunately, for the storm simulated here we did not have total lightning information and a scaling study of P92 and D08 was not possible.

\section{Conclusions}

The results of this work suggest that, the presence of biological ice nuclei active at relatively warm temperatures, and in particular the bacterium $P$. syringae, can induce an increase in cloud ice, which in turn induces an increase of cloud electricity. From both lightning frequency calculations, D08 and P92, the simulations S4 and S6 are from 3.1 to 3.7 higher than the BRAMS default S5; even S2 and S3, with lower 
bacterium concentrations, are 3 times higher. It must be clarified, that these simulations deal with small idealized clouds with short life and involve very simple numerical modeling. Therefore, the results of this simple numerical modeling emphasize that biological IN or any IN with warm temperature activity (warmer than $-8^{\circ} \mathrm{C}$ ) are relevant for cloud electricity, as has been suggested previously in the work of Phillips et al. (2009). Additionally, this work, Phillips et al. (2009), found that INA can influence significantly the average number and size of crystals in the clouds; the horizontal cloud coverage, precipitation and radiative properties and they open questions about whether emissions of IN particles can be modified by their own effects on clouds and atmospheric conditions. Besides, Michaud et al. (2011) observed that centers of hailstones contain much more bacteria than the surrounding air which emphasizes all results.

It must be notified the simulated rain total decrease, about $8 \%$, is in agreement with literature such as Levin et al. (2005).

BRAMS and RAMS default IN concentration seems to play a secondary role, affecting weakly the total number of flashes. Future works should consider modifying the default parameters $\left(-8^{\circ} \mathrm{C}\right)$ to explore deeper convective storms in other realistic contexts that involve more detailed parameterization of the hydrometeor concentrations. Also, a more detailed study on the relationships between the observed and simulated storm parameters and microphysics is needed before further conclusions can be taken from the actual number lightning flashes produced, as showed by Barthe et al. (2010).

The real biological IN activity inside of clouds is a rather unknown factor with many implications, including cloud tops, rainfall amount and cloud albedo as examples, as emphasized by Phillips et al. (2009), cited above. Additionally, there are many other biological materials acting as IN such as fungal spores, algae, pollen, other bacterial species, etc. (Morris et al., 2004; Pouleur et al., 1992), that when taken together may have an even more important potential impacts on cloud parameters and cloud electricity. Additionally, cloud electrification, by itself, has many important impacts, among them, public security and $\mathrm{NO}_{\mathrm{x}}$ production.

Acknowledgements. We thank the Epicurus Fund at Donors Trust for a generous donation to fund research meetings between the first and last author leading to the conception and realization of this work. We also gratefully acknowledge the reviewers for their comments and suggestions which improved the article.

Edited by: C. Hoose

\section{References}

Albrecht, R. I.: Electrification of precipitating systems over the Amazon: Physical and dynamical processes of thunderstorm development, Ph.D. Dissertation, University of Sao Paulo, Sao Paulo, Brazil, 2008 (in Portuguese).
Albrecht, R. I., Morales, C. A., and Silva Dias, M. A. F.: One dimension cloud model with electrification scheme: The dependence of the CCNS on the development of the electrical charge center, Proc. 15th International Conference on Clouds and Precipitation, Cancun, Mexico, 2008.

Altaratz, O., Reisin, T., and Levin, Z.: Simulation of the electrification of winter thunderclouds using the three-dimensional Regional Atmospheric Modeling System (RAMS) model: Single cloud simulations, J. Geophys. Res., 110, D20205, doi:10.1029/2004JD005616, 2005.

Amato, P., Menager, M., Sancelme, M., Laj, P., Mailhot, G., and Delort, A.-M.: Microbial population in cloud water at the Puy de Dôme, Implications for the chemistry of clouds, Atmos. Environ., 39, 4143-4153, 2005.

Amato, P., Parazols, M., Sancelme, M., Laj, P., Mailhot, G., and Delort, A.-M.: Microorganisms isolated from the water phase of tropospheric clouds at the Puy de Dôme: major groups and growth abilities at low temperatures, FEMS-Microbiol. Ecol., 49, 242254, 2007.

Ariya, P. A. and Amyot, M.: New directions: The role of bioaerosols in atmospheric chemistry and physics, Atmos. Environ., 38, 1231-1232, 2004.

Barthe, C. and Pinty, J.-P.: Simulation of electrified storms with comparison of the charge structure and lightning efficiency, J. Geophys. Res., 112, D19204, doi:10.1029/2006JD008241, 2007.

Barthe, C., Deierling, W., and Barth, M. C.: Estimation of total lightning from various storm parameters: A cloudresolving model study, J. Geophys. Res., 115, D24202, doi:10.1029/2010JD014405, 2010.

Bauer, H., Giebl, H., Hitzenberger, R., Kasper-Giebl, A., Reischl, G., Zibuschka, F., and Puxbaum, H.: Airborne bacteria as cloud condensation nuclei, J. Geophys. Res., 108, AAC2/1-AAC2/5, 2003.

Blyth, A. M., Christian, H. J., Driscoll, K., Gadian, A. M., and Latham, J.: Determination of ice precipitation rates and thunderstorm anvil ice contents from satellite observations of lightning, Atmos. Res., 59-60, 217-229, 2001.

Boccippio, D. J., Koshak, W. J., and Blakeslee, R. J.: Performance assessment of the Optical Transient Detector and Lightning Imaging Sensor. Part I: Predicted diurnal variability, J. Atmos. Ocean. Tech., 19, 1318-1332, 2002.

Christner, B. C., Morris, C. E., Foreman, C. M., Cai, R., and Sands, D. C.: Ubiquity of biological ice nucleators in snowfall, Science, 319, 1214, doi:10.1126/science.1149757, 2008.

Cotton, W. R., Tripoli, G. J., Rauber, R. M., and Mulvihill, E. A.: Numerical simulation of the effects of varying ice crystal nucleation rates and aggregation processes on orographic snowfall, J. Clim. Appl. Meteorol., 25, 1668-1680, 1986.

Deierling, W., Petersen, W. A., Latham, J., Ellis, S., and Christian, H. J.: The relationship between lightning activity and ice fluxes in thunderstorms, J. Geophys. Res., 113, D15210, doi:10.1029/2007JD009700, 2008.

Deguillaume, L., Leriche, M., Amato, P., Ariya, P. A., Delort, A.M., Pöschl, U., Chaumerliac, N., Bauer, H., Flossmann, A. I., and Morris, C. E.: Microbiology and atmospheric processes: chemical interactions of primary biological aerosols, Biogeosciences, 5, 1073-1084, doi:10.5194/bg-5-1073-2008, 2008.

DeMott, P. J., Meyers, M. P., and Cotton, W. R.: Parameterization and impact of ice initiation 755 processes relevant to numerical 
model simulations of cirrus clouds, J. Atmos. Sci., 51, 77-90, 1994.

Diehl, K. and Wurzler, S.: Air parcel model simulations of a convective cloud: Bacteria acting as immersion ice nuclei, Atmos. Environ., 44, 4622-4628, 2010.

Diehl, K., Matthias-Maser, S., Mitra, S. K., and Jaenicke, R.: Laboratory studies on the ice nucleating ability of biological aerosol particles in condensation freezing, immersion freezing and contact freezing modes, J. Aerosol Sci., 31, S70-S71, 2000.

Dye, J. E., Jones, J. J., and Winn, W. P.: Observations within two regions of charge during initial thunderstorm electrification, Q. J. Roy. Meteor. Soc., 114, 1271-1290, 1989.

Elbert, W., Taylor, P. E., Andreae, M. O., and Pöschl, U.: Contribution of fungi to primary biogenic aerosols in the atmosphere: wet and dry discharged spores, carbohydrates, and inorganic ions, Atmos. Chem. Phys., 7, 4569-4588, doi:10.5194/acp-7-4569-2007, 2007.

Freitas, S. R., Longo, K. M., Silva Dias, M. A. F., Chatfield, R., Silva Dias, P., Artaxo, P., Andreae, M. O., Grell, G., Rodrigues, L. F., Fazenda, A., and Panetta, J.: The Coupled Aerosol and Tracer Transport model to the Brazilian developments on the Regional Atmospheric Modeling System (CATT-BRAMS) - Part 1: Model description and evaluation, Atmos. Chem. Phys., 9, 28432861, doi:10.5194/acp-9-2843-2009, 2009.

Gonçalves, F. L. T., Martins, J. A., and Silva Dias, M. A. F.: Shape parameter analysis using cloud spectra and gamma functions in the numerical modeling RAMS during LBA Project at Amazonian region, Brazil, Atmos. Res., 89, 1-11, 2008.

Hallett, J. and Mossop, S. C.: Production of secondary ice particles during riming process, Nature, 249, 26-28, 1974.

Hamilton, W. D., Lenton, T. M., Spora and Gaia: How microbes fly with their clouds, Ethol. Ecol. Evol., 10, 1-16, 1998.

Helsdon Jr., J. H., Wojcik, W. A., and Farley, R. D.: An examination of thunderstorm-charging mechanisms using a two-dimensional storm electrification model, J. Geophys. Res., 106, 1165-1192, doi:10.1029/2000JD900532, 2001.

Hoose, C., Kristjánsson, J. E., and Burrows, S. M.: How important is biological ice nucleation in clouds on a global scale?, Environ. Res. Lett., 5, 1-7, doi:10.1088/1748-9326/5/2/024009, 2010.

Jaenicke, R.: Abundance of cellular material and proteins in the atmosphere. Science, 308, 5718, doi:10.1126/science.1106335, 2005.

Latham, J., Blyth, A. M., Christian, H. J., Deierling, W., and Gadian, A. M.: Determination of precipitation rates and yields from lightning measurements, J. Hydrol., 288, 13-19, 2004.

Latham, J., Petersen, W. A., Deierling, W., and Christian, H. J.: Field identification of a unique globally dominant mechanism of thunderstorm electrification, Q. J. R. Meteor. Soc., 133, 14531457, 2007.

Levin, Z., Teller, A., Ganor, E., and Yin, Y.: On the interactions of mineral dust, sea-salt particles, and clouds: A measurement and modeling study from the Mediterranean Israel Dust Experiment campaign, J. Geophys. Res., 110, D20202, doi:10.1029/2005JD005810, 2005.

Mansell, E., MacGorman, D. R., Ziegler, C. L., and Straka, J. M.: Charge structureand lightning sensitivity in a simulated multicell thunderstorm, J. Geophys. Res., 110, D12101, doi:10.1029/2004JD005287, 2005.
Martins, J. A. and Silva Dias, M. A. F.: The impact of smoke from forest fires on the spectral dispersion of cloud droplet size distributions in the Amazonian region, Environ. Res. Lett., 4, 015002, doi:10.1088/1748-9326/4/1/015002, 2009.

Martins, J. A., Silva Dias, M. A. F., and Gonçalves, F. L. T.: Impact of biomass burning aerosols on precipitation in the Amazon: A modeling case study, J. Geophys. Res., 114, 1-68, 2009.

MacGorman, D. R. and Rust, W. D.: The electrical nature of storms, Oxford University Press, New York, 422 pp., 1998.

Meyers, M. P., Walko, R. L., Harrington, J. Y., and Cotton, W. R.: New RAMS cloud microphysics parameterization. Part II: The two-moment scheme, Atmos. Res., 45, 3-39, 1997.

Michaud, A. B., Sands, D. C., Dore, J. E., Leslie, D., Lyons, W. B., and Priscu, J. C.: The Role of Ice Nucleating Bacteria in Hailstone Formation, 11th General Meeting of the American Society for Microbiology, New Orleans, 2011.

Möhler, O., DeMott, P. J., Vali, G., and Levin, Z.: Microbiology and atmospheric processes: the role of biological particles in cloud physics, Biogeosciences, 4, 1059-1071, doi:10.5194/bg-4-10592007, 2007.

Möhler, O., Georgakopoulos, D. G., Morris, C. E., Benz, S., Ebert, V., Hunsmann, S., Saathoff, H., Schnaiter, M., and Wagner, R.: Heterogeneous ice nucleation activity of bacteria: new laboratory experiments at simulated cloud conditions, Biogeosciences, 5, 1425-1435, doi:10.5194/bg-5-1425-2008, 2008.

Morris, C. E., Georgakapoulos, D., and Sands, D. C.: Ice nucleation active bacteria and their potential role in precipitation, J. Phys. IV, 121, 87-103, 2004.

Morris, C. E., Sands, D. C., Vinatzer, B. A., Glaux, C., Guilbaud, C., Buffière, A., Yan, S., Dominguez, H., and Thompson, B. M.: The life history of the plant pathogen Pseudomonas syringae is linked to the water cycle, ISME J., 2, 321-334, 2008.

Morris, C. E., Sands, D. C., Vanneste, J. L., Montarry, J., Oakley, B., Guilbaud, C., and Glaux, C.: Inferring the evolutionary history of the plant pathogen Pseudomonas syringae from its biogeography in headwaters of rivers in North America, Europe and New Zealand, mBio, 1, e00107-10-e00107-20, 2010.

Morris, C. E., Sands, D. C., Bardin, M., Jaenicke, R., Vogel, B., Leyronas, C., Ariya, P. A., and Psenner, R.: Microbiology and atmospheric processes: research challenges concerning the impact of airborne micro-organisms on the atmosphere and climate, Biogeosciences, 8, 17-25, doi:10.5194/bg-8-17-2011, 2011.

Orser, C., Staskawicz, B. J., Panopoulos, N. J., Dahlbeck, D., and Lindow, S. E.: Cloning and expression of bacterial ice nucleation genes in Escherichia coli, J. Bacteriol., 184, 359-366, 1985.

Pereyra, R. G., Avila, E. E., Castellano, N. E., and Saunders, C.: A laboratory study of graupel charging, J. Geophys. Res., 105, 20803-20812, 2000.

Petersen, W. A., Christian, H. J., and Rutledge, S. A.: TRMM observations of the global relationship between ice water content and lightning, Geophys. Res. Lett., 32, L14819, doi:10.1029/2005GL023236, 2005.

Phillips, V. T. J., Andronache, C., Christner, B., Morris, C. E., Sands, D. C., Bansemer, A., Lauer, A., McNaughton, C., and Seman, C.: Potential impacts from biological aerosols on ensembles of continental clouds simulated numerically, Biogeosciences, 6 , 987-1014, doi:10.5194/bg-6-987-2009, 2009.

Pöschl, U., Martin, S. T., Sinha, B., Chen, Q., Gunthe, S. S., Huffman, J. A., Borrmann, S., Farmer, D. K., Garland, R. M., 
Helas, G., Jimenez, J. L., King, S. M., Manzi, A., Mikhailov, E., Pauliquevis, T., Petters, M. D., Prenni, A. J., Roldin, P., Rose, D., Schneider, J., Su, H., Zorn, S. R., Artaxo, P., and Andreae, M. O.: Rainforest Aerosols as Biogenic Nuclei of Clouds and Precipitation in the Amazon, Science, 17, 1513-1516, 2010.

Price, C. and Rind, D.: A Simple Lightning Parameterization for Calculating Global Lightning Distributions, J. Geophys. Res., 97, 9919-9933, doi:10.1029/92JD00719, 1992.

Pruppacher, H. R. and Klett, J. D.: Microphysics of clouds and precipitation, Atmospheric and oceanographic sciences library; 18, Kluwer, Dordrecht, 2. Rev. and Enl. Edn., 1997.

Pouleur, S., Richard, C., Martin, J. G., and Antoun, H.: Ice Nucleation Activity in Fusarium acuminatum and Fusarium avenaceum, Appl. Environ. Microbiol., 58, 2960-2964, 1992.

Rakov, V. A. and Uman, M. A.: Lightning: Physics and Effects, Cambridge: Cambridge University Press, 687 pp., 2003.

Reynolds, S. E., Brooks, M., and Gourley, M. F.: Thunderstorm charge separation, J. Meteorol., 14, 163-178, 1957.

Rutledge, S. A., Williams, E. R., and Keenan, T. D.: The down under Doppler and electricity experiment (DUNDEE): Overview and preliminary results, B. Am. Meteorol. Soc., 73, 3-16, 1992.

Sands, D. C., Langhans, V. E., Scharen, A. L., and de Smet, G.: The association between bacteria and rain and possible resultant meteorological implications, J. Hungarian Meteorol. Serv., 86, 148-152, 1982.

Saunders, C. P. R., Keith, W. D., and Mitzeva, R. P.: The effect of liquid water on thunderstorm charging, J. Geophys. Res., 96, 11007-11017, 1991.

Saunders, C. P. R., Bax-Norman, H., Emersic, C., Avila, E. E., and Castellano, N. E.: Laboratory studies of the effect of cloud conditions on graupel/crystal charge transfer in thunderstorm electrification, Q. J. Roy. Meteorol. Soc., 132, 2653-2673, doi:10/1256/qj.05.218, 2006.
Sattler, B., Puxbaum, H., and Psenner, R.: Bacterial growth in supercooled cloud droplets, Geophys. Res. Lett., 28, 239-242, 2001.

Schumann, U. and Huntrieser, H.: The global lightning-induced nitrogen oxides source, Atmos. Chem. Phys., 7, 3823-3907, doi:10.5194/acp-7-3823-2007, 2007.

Szyrmer, W. and Zawadzki, I.: Biogenic and anthropogenic sources of ice-forming nuclei: A review, B. Am. Meteorol. Soc., 78, 209-228, 1997.

Takahashi, T.: Riming electrification as a charge generation mechanism in thunderstorms, J. Atmos. Sci., 35, 1536-1548, 1978.

Takahashi, T. and Miyawaki, K.: Reexamination of riming electrification in a wind tunnel, J. Atmos. Sci., 59, 1018-1025, 2002.

Tripoli, G. J. and Cotton, W. R.: The Colorado State University three-dimensional cloud mesoscale model, Part I: General theoretical framework and sensitivity experiments, J. Rech. Atmos., 16, 185-220, 1982.

Vonnegut, B.: Some facts and speculations concerning the origin and role of thunderstorm electricity, Meteorol. Monogr., 5, 224 241, 1963.

Walko, R., Cotton, W. R., Meyers, M. P., and Harrington, J. Y.: New RAMS cloud microphysics parameterization. Part I: The singlemoment scheme, Atmos. Res., 38, 29-62, 1995.

Williams, E. R.: Large-Scale Charge Separation in Thunderclouds, J. Geophys. Res., 90, 6013-6025, doi:10.1029/JD090iD04p06013, 1985.

Williams, E. R. and Lhermitte, R. M.: Radar tests of the precipitation hypothesis for thunderstorm electrification, J. Geophys Res., 88, 10984-10992, 1983.

Yoshida, S., Morimoto, T., Ushio, T., and Kawasaki, Z.: A fifthpower relationship for lightning activity from Tropical Rainfall Measuring Mission satellite observations, J. Geophys. Res., 114, D09104, doi:10.1029/2008JD010370, 2009. 